\title{
High energy density materials based on fluorinated bridged trinitromethyl azo triazole derivatives: a quantum chemical study of thermodynamic and energetic properties
}

\author{
Clemence Ansbert ${ }^{1,2}$ - Alexander Pogrebnoi ${ }^{1} \cdot$ Tatiana Pogrebnaya $^{1}$
}

Received: 26 June 2020 / Accepted: 12 October 2020 / Published online: 19 October 2020

(c) Springer Nature Switzerland AG 2020

\begin{abstract}
High energy density materials (HEDM) have gained extensive attention due to their energetic properties and safety issues. Nitro and fluoro groups, among others, have become viable substituents on the triazole framework because of their particular contribution to detonation properties and moderate sensitivity. In this study, Density Function Theory (DFT) approach was employed to design fluorinated bis(trinitromethyl) azo triazoles. The molecular structures, thermodynamic properties of gaseous species (e.g., enthalpies of detonation and enthalpies of formation) and energetic properties of solid materials (detonation heat Q, pressure PD and velocity VD) have been investigated. The best characteristics attained for the designed azo fluorinated solid compounds are as follows: Q 1650-1690 $\mathrm{cal} \mathrm{g}^{-1}$, PD 44-46 GPa and VD $9.8 \mathrm{~km} \mathrm{~s}^{-1}$. These characteristics are superior to those of conventional explosives, indicating that fluorinated bis(trinitromethyl) azo triazoles are promising HEDM.
\end{abstract}

Keywords High energy density materials · Fluorinated bis(trinitromethyl) azo triazoles · DFT · Thermodynamic and energetic properties

\section{Introduction}

Modified highly nitrated organic compounds are emerging alternatives to traditional explosives [1]. A contemporary tactic to the field of energetic materials is to substitute some explosives with energetic groups containing materials [2-4]. These compounds contain a high proportion of energetic groups relative to traditional high energy density materials (HEDM) [5-12]; and burn more cleanly producing less soot, less carbon monoxide and the primary product of explosion is a gas (usually $\mathrm{CO}, \mathrm{CO}_{2}, \mathrm{HF}$, $\mathrm{N}_{2}$ and $\mathrm{F}_{2}$ ) [13]. In recent years, HEDM have attracted widespread attention owing to relatively high efficiency, environmental friendliness and excellent performance $[5,14]$. Various designs of HEDM have been based on the introduction of explosophoric groups (nitro, azido and azo) and active moieties such as $\mathrm{C}\left(\mathrm{NO}_{2}\right)_{2} \mathrm{~F}$ and $\mathrm{C}\left(\mathrm{NO}_{2}\right)_{3}$ to a nitrogen-containing framework $[11,15,16]$. These are the oxygen-rich groups that provide balance for intermolecular combustion leading to facilitated detonation reaction and enhanced energetic performance $[9,17,18]$.

The desired properties such as elevated heat of detonation, detonation pressure and velocity, density of the material, and moderate sensitivity can be achieved by

Electronic supplementary material The online version of this article (https://doi.org/10.1007/s42452-020-03670-6) contains supplementary material, which is available to authorized users.

$\triangle$ Clemence Ansbert, ansbertc@nm-aist.ac.tz; Alexander Pogrebnoi, alexander.pogrebnoi@nm-aist.ac.tz; Tatiana Pogrebnaya, tatiana.pogrebnaya@nm-aist.ac.tz| ${ }^{1}$ Department of Materials and Energy Science and Engineering, The Nelson Mandela African Institution of Science and Technology, P. O Box 447, Arusha, Tanzania. ${ }^{2}$ Department of Science, Mwenge Catholic University, P. O Box 1226, Moshi, Tanzania. 
choosing the number, type and position of the substituent groups in the framework $[19,20]$. These properties can be attained by introducing an energetic group to a nitrated compound such that during detonation, a lot of energy is generated [21]. The design of new energetic materials can be done by increasing the number of nitro- or other active groups in the molecular framework $[11,15]$. Fluorinated compounds were subjected to a thorough investigation due to their exceptional detonation properties $[2,19,22$, 23]. High fluorine content together with hydrogen results in the formation of hydrogen fluoride upon detonation and a high amount of energy release $[2,19,23]$.

Triazole heterocycles offer a suitable framework for the development of energetic materials by chemical modification using various functional groups to attain a desired set of properties $[6,11]$. Bridged triazoles have been studied and found to be thermally stable with a positive enthalpy of formation [6]. Besides, Zhang Junlin et al. [23] prepared three fluorinated energetic compounds by a straightforward synthesis with varied degree of fluorination whereby the stability and performance were improved. In our study, we designed new high energy density materials via the introduction of fluorine atoms into trinitromethyl azo triazoles aimed at enhancing energetic properties; we proposed mono, di, tri and tetra fluorobis(trinitromethyl) azo triazoles molecules (Scheme 1) and investigated their properties.

\section{Computational details}

\subsection{Computations of structural and thermodynamic properties}

Density functional theory DFT/B3LYP [24] with 6-31G(d,p) basis set was used for optimization of ground state geometries and frequencies calculations for each molecule. Similar approach was used, for example, by Wei et al. [25] for investigation of tetrazine-based HEDM. The absence of imaginary frequencies confirmed that the obtained geometries corresponded to energy minima on the potential energy surfaces. Quantum chemical calculations were performed with the Gaussian 09 software [26]. Thermodynamic characteristics of reactions were obtained with extended 6-311++G(d,p) basis set. Based on the optimized geometrical parameters and vibrational frequencies, the thermodynamic functions (TDF) of gaseous species were calculated applying the 'rigid rotor-harmonic oscillator' approximation with OpenThermo software [27]. The electrostatic potential surface properties (molecular surface area, volume, charge balance and molecular density) were analyzed using Multiwfn software [28]. Molecular design, visualization of molecular and electronic structures, IR spectra were done by using Avogadro [29], GaussView05 [26] and ChemCraft [30] software.<smiles>CC(C)(C)c1nncn1/N=N/n1cnnc1C(=O)O[Na]</smiles>

A<smiles></smiles>

D<smiles>O=C(O[Na])c1nnc(F)n1N(F)N(F)n1c(F)nnc1C(=O)[N+]([O-])([O-])[O-]</smiles><smiles>O=C([O-])c1nncn1N(F)Nn1cnnc1C(=O)[N+](=O)[O-]</smiles>

B<smiles>CC(C)(C)c1nnc(C([N+](=O)[O-])([N+](=O)[O-])[N+]([O-])([O-])[O-])n1/N=N/n1c(F)nnc1F</smiles><smiles>CC(c1nncn1/N=N/n1c(F)nnc1C([O-])([N+]([O-])O)[N+](=O)[O-])([N+](=O)[O-])[N+](=O)[O-]</smiles>

C<smiles>CC(C)(C)c1nncn1N(F)N(F)n1cnnc1C([O-])([N+](=O)[O-])[N+]([O-])([O-])O</smiles>

Scheme 1 Structural formulae: non-fluorinated (A) and designed fluorinated molecules (B-G) 
The energies of reactions $\left(\Delta_{\mathrm{r}} E\right)$ were calculated by considering the difference between the total energies of the products $\left(\Sigma E_{\text {prod }}\right)$ and reactants $\left(\Sigma E_{\text {react }}\right)$ :

$\Delta_{\mathrm{r}} E=\Sigma E_{\text {prod }}-\Sigma E_{\text {react }}$

The enthalpies of the reactions were computed by adding the zero-point vibration energies ( $\left.\Delta_{\mathrm{r}} \mathrm{ZPVE}\right)$ to the $\Delta_{\mathrm{r}} E$ :

$\Delta_{\mathrm{r}} H^{\circ}(\mathrm{g}, 0)=\Delta_{\mathrm{r}} E+\Delta_{\mathrm{r}} \mathrm{ZPVE}$

To compute the enthalpy of formation of a gaseous species, we first calculated the enthalpy of formation at $0 \mathrm{~K}, \Delta_{\mathrm{f}} \mathrm{H}^{\circ}(\mathrm{g}, 0)$, and then enthalpy of formation at $298 \mathrm{~K}$, $\Delta_{\mathrm{f}} H^{\circ}(\mathrm{g}, 298)$ :

$\Delta_{\mathrm{f}} H^{\circ}(\mathrm{g}, 0)=\Sigma \Delta_{\mathrm{f}} H_{\text {prod }}^{\circ}(\mathrm{g}, 0)-\Delta_{\mathrm{r}} H^{\circ}(\mathrm{g}, 0)$

$\Delta_{\mathrm{f}} H^{\circ}(\mathrm{g}, 298)=\Sigma \Delta_{\mathrm{f}} H_{\text {prod }}^{\circ}(\mathrm{g}, 298)-\Delta_{\mathrm{r}} H^{\circ}(\mathrm{g}, 298)$

$\Delta_{\mathrm{r}} H^{\circ}(\mathrm{g}, 298)=\Delta_{\mathrm{r}} H^{\circ}(\mathrm{g}, 0)+\Delta_{\mathrm{r}}\left[H^{\circ}(\mathrm{g}, 298)-H^{\circ}(\mathrm{g}, 0)\right]$

where $\Delta_{\mathrm{r}}\left[H^{\circ}(g, 298)-H^{\circ}(g, 0)\right]$ is the enthalpy increment of the reaction. The enthalpies of formation and enthalpy increments of small gaseous species involved in reaction have been taken from the IVTANTHERMO database [31]. For the solid phase species, enthalpies of formation $\Delta_{\mathrm{f}} H^{\circ}(\mathrm{c}$, 298) were calculated as follows:

$\Delta_{\mathrm{f}} H^{\circ}(\mathrm{c}, 298)=\Delta_{\mathrm{f}} H^{\circ}(\mathrm{g}, 298)-\Delta_{\text {sub }} H^{\circ}(298)$

The enthalpy of sublimation $\Delta_{\text {sub }} H^{\circ}(298)$ was obtained as described in $[7,32,33]$ :

$\Delta_{\text {sub }} H^{\circ}(298)=h A^{2}+i\left(v \sigma_{\text {tot }}^{2}\right)^{0.5}+j$

where $A$ is the molecular surface area, $v \sigma_{\text {tot }}^{2}$ is the electrostatic interaction index; both obtained from the Multiwfn program package [28]; and the $h, i$, and $j$ are the fitting parameters adopted from Byrd and Rice [32].

The Gibbs free energy is the measure of reaction spontaneity calculated by the following equation:

$\Delta_{\mathrm{r}} G^{\circ}(T)=\Delta_{\mathrm{r}} H^{\circ}(0)+\Delta_{\mathrm{r}}\left[H^{\circ}(T)-H^{\circ}(0)\right]-T \Delta_{\mathrm{r}} S^{\circ}(T)$

where $\Delta_{\mathrm{r}}\left[H^{\circ}(T)-H^{\circ}(0)\right]$ is the enthalpy increment and $\Delta_{\mathrm{r}} S^{\circ}(T)$ entropy of the reaction.

\subsection{Computation of energetic properties}

Energetic properties indicate how the materials are powerful upon detonation. They include; molecular density $\left(\rho_{\text {mol }}\right)$, detonation velocity (VD) and pressure (PD), detonation heat $(\mathrm{Q})$, impact sensitivity $\left(\mathrm{h}_{50 \%}\right)$, and oxidation coefficient (a). The density of molecules was estimated in terms of atoms in a molecule $[34,35]$ as suggested by Politzer [36]:

$\rho_{\mathrm{mol}}=0.9183\left(\frac{\mathrm{M}_{\mathrm{W}}}{\mathrm{V}}\right)+0.0028\left(v \sigma_{\text {tot }}^{2}\right)+0.0443, \mathrm{~g} \mathrm{~cm}^{-3}$

where $V$ is the volume enclosed by the 0.001 atomic unit contour of electron density of the molecule, $M_{w}$ is the molar mass of the compound, and $u \sigma^{2}$ tot is the index of electrostatic interaction obtained using Multiwfn program package [28].

The detonation velocity VD and pressure PD indicate how the material is potent upon detonation. The higher are the values of these parameters, the better the performance of the material. The parameters were estimated using the following equations [5, 14, 37-41]:

$\mathrm{VD}=1.01(\sqrt{\mathrm{N} \sqrt{\mathrm{MQ}}})\left(1+1.30 \rho_{\mathrm{mol}}\right), \mathrm{km} \mathrm{s}^{-1}$

$\mathrm{PD}=1.56 \rho^{2} \mathrm{~N} \sqrt{\mathrm{MQ}}, \mathrm{GPa}$

where $\mathrm{N}$ stands for the number of moles of gases produced per gram of the material upon detonation.

$\mathrm{N}=\frac{\Sigma n_{\text {prod }}}{\mathrm{M}_{\mathrm{W}}}$

Hence the inverse $\mathrm{N}$ gives the average molecular mass $M$ of all detonation products:

$M=\frac{M_{W}}{\Sigma n_{\text {prod }}}$

The detonation heat is

$\mathrm{Q}=-\left(\frac{\sum \Delta_{\mathrm{f}} H_{\text {prod }}^{\circ}(\mathrm{g}, 298)-\Delta_{\mathrm{f}} H^{\circ}(\mathrm{c}, 298)}{\mathrm{M}_{\mathrm{W}}}\right), \mathrm{cal} \mathrm{g}^{-1}$

The impact sensitivity, $\mathrm{h}_{50 \%}$ was obtained using the generalized interact property function [5, 42]:

$\mathrm{h}_{50 \%}=29.3+0.001386 \exp (48.84 \mathrm{v}), \mathrm{cm}$

where $u$ is the index of charge balance obtained using Multiwfn program package [28].

The coefficient of oxidation a indicates how well the material provides its own oxidant [19]. The increase in a increases the ability of the materials' self-oxidation [19]. For the compound with the molecular formula $\mathrm{C}_{x} \mathrm{H}_{y} \mathrm{~N}_{w} \mathrm{O}_{z} \mathrm{~F}_{v}$, the coefficient of oxidation is estimated as follows [19]: 


$$
\alpha=\frac{\left(z+\frac{v}{2}\right)}{\left(2 x+\frac{y}{2}\right)}
$$

\section{Results and discussion}

\subsection{Geometrical properties}

In our design, we have started from the trinitromethyl azo triazoles and then introduced fluorine atoms into azo group or/and triazole rings replacing the available hydrogen atoms. It is anticipated that introduction of fluorine atoms and the presence of trinitromethyl moieties will contribute to the energy density while azo and triazole skeleton rings will increase the stability of the molecule.

The optimized configurations of the molecules are shown in Fig. 1; the most relevant geometrical parameters are given in Table 1.

The analysis of the optimized parameters shows that the addition of fluorine atoms to the original trinitromethyl azo triazole molecule $A$ affects mostly the nearest bonds as well as the planarity of the structure. In the molecules $B$, $D, F$ and $G$ where the F-atoms are added to the azo chain, the formed $\mathrm{N}-\mathrm{F}$ bonds are maintained perpendicular to the chain moiety and the central double $\mathrm{N}=\mathrm{N}$ bond transforms into the single bond which brings an elongation of the $R_{2}\left(\mathrm{~N}_{4}-\mathrm{N}_{5}\right)$ from 1.246 up to $1.511 \AA$. When the fluorine atoms are attached to the triazole rings (molecules $\mathrm{C}, \mathrm{E}$, $F, G$ ), they just replace the hydrogen atoms forming alike C-F bonds of 1.302-1.304 A length while keeping the rings coplanarity and slightly increasing bond angles $\mathrm{N}-\mathrm{C}-\mathrm{N}$ from $109^{\circ}$ to $112^{\circ}$. All compounds except $G$ have close to a coplanar structure, dihedral angles between the rings and in the chain $\mathrm{N}-\mathrm{N}-\mathrm{N}-\mathrm{N}$ range from $173^{\circ}$ to $180^{\circ}$, whereas the molecule $\mathrm{G}$ with four $\mathrm{F}$ atoms, two at the chain and two at the rings, has a bent configuration with the angles $\varphi_{1}\left(\mathrm{C}_{1}-\mathrm{N}_{3}-\mathrm{N}_{6}-\mathrm{C}_{4}\right)=78^{\circ}$ and $\chi(\mathrm{N}-\mathrm{N}-\mathrm{N}-\mathrm{N})=154^{\circ}$.

\subsection{Vibrational analysis}

The computed vibrational spectra of the designed molecules confirmed the absence of imaginary frequencies; the simulated IR absorption spectra are shown in Fig. 2. For all compounds, most intensive peaks between $\sim 1700$ and $1740 \mathrm{~cm}^{-1}$ are assigned to asymmetric stretching of $\mathrm{N}=\mathrm{O}$ bonds in the trinitromethyl moieties and lower peaks between 806 and $815 \mathrm{~cm}^{-1}$ to bending vibrations of the same bonds. Other strong absorptions near $1350 \mathrm{~cm}^{-1}$ and $1370-1430 \mathrm{~cm}^{-1}$ correspond to stretching vibrations of $\mathrm{C}-\mathrm{N}$ bonds of the trinitromethyl moieties and $\mathrm{C}-\mathrm{N}$ bonds of the triazole rings, respectively. Besides, there are weak absorption peaks at $\sim 600-740 \mathrm{~cm}^{-1}$ which correspond to the bending vibrations of the triazole rings. For the fluorinated compounds $B, D, F$ and $G$, the stretching vibrations of $\mathrm{N}-\mathrm{F}$ bonds of the hydrazine group are seen at $\sim 900-955 \mathrm{~cm}^{-1}$. For the molecules $C, E, F$ and $G$, the sharp absorption peaks at $\sim 1650 \mathrm{~cm}^{-1}$ correspond to $C-F$ stretching of the triazole skeleton.

\subsection{Electronic structure}

The intramolecular energy transfer within the material can be understood through molecular orbitals analysis. It is expected that good HEDMs should have a distinct separation of electron density between the HOMO and LUMO and reasonably small energy gap $E_{\mathrm{g}}$ for electrons transition. Also it was noticed that in some cases a correlation between energy gap and sensitivity of the explosive materials may exist $[43,44]$. Negative correlation between energy gap and detonation velocity or pressure was reported in [46]. For our seven compounds $A-G$, the frontier molecular orbitals and energy gaps are displayed in Fig. 3. The green colour denotes the negative phase, and deep red indicates the positive phase. Higher electron density is found near atoms/groups which possess higher electronegativity; here they are fluorine and nitrogen atoms in the rings or nitro groups. Redistribution of electron density between the HOMO and LUMO is clearly seen for the fluorinated species $B, D, F$ and $G$ while not observed for others ( $A, C$ and $E$ ). Therefore the fluorine attachment to the hydrazine chain favours the transfer of electrons in the HOMO $\rightarrow$ LUMO transition. The energy gap increases upon fluorine attachment to the triazole rings, $A(3.64 \mathrm{eV})<C(4.17 \mathrm{eV})<E(4.27 \mathrm{eV})$, but when $\mathrm{F}$ atoms join the central hydrazine group, the $E_{\mathrm{g}}$ decreases, $\mathrm{B}$ $(3.26 \mathrm{eV})<\mathrm{D}(3.78 \mathrm{eV})<\mathrm{F}(3.84 \mathrm{eV})<\mathrm{G}(4.18 \mathrm{eV})$. The highest $E_{\mathrm{g}}=4.27 \mathrm{eV}$ is obtained for the $\mathrm{E}$ compound and the lowest $E_{\mathrm{g}}=3.26 \mathrm{eV}$ is for $\mathrm{B}$ molecule. This indicates that the addition of fluorine on the azo chain is helpful in decreasing the energy gap. These values are comparable to the experimental $E_{\mathrm{g}}$ values for traditional explosive compounds; $3.4 \mathrm{eV}$ (RDX) [45], $4.27 \mathrm{eV}$ (PETN) [46] and $5.32 \mathrm{eV}$ (HMX) [46]. Therefore, the compounds B and D for which the requirements of good electron density separation and smaller energy gaps are met, are anticipated to be better HEDM.

\subsection{Thermodynamics of detonation and combustion reactions}

Detonation and combustion reactions with formation of simple products $\mathrm{CO}, \mathrm{CO}_{2}, \mathrm{H}_{2} \mathrm{O}, \mathrm{HF}, \mathrm{F}_{2}$ and others, have been considered for gaseous compounds $A-G$ (Table 2 ). 

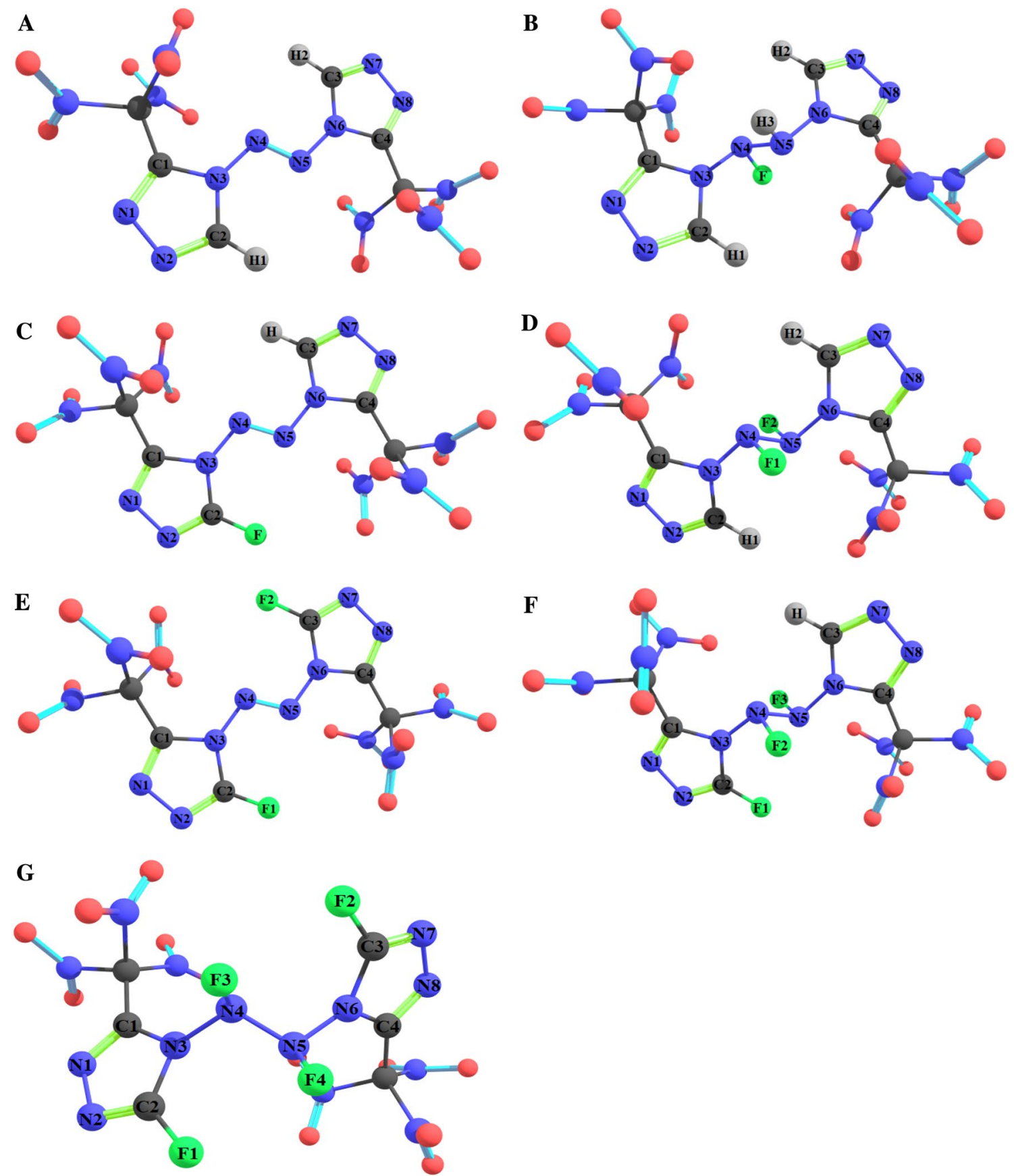

Fig. 1 Optimized molecular structures of non-fluorinated $(A)$ and designed fluorinated bridged triazole derivatives (B-G)

Energies $\Delta_{\mathrm{r}} E$ and enthalpies $\Delta_{\mathrm{r}} H^{\circ}(0)$ of the reactions have been computed using Eqs. (1) and (2). As is seen, all reactions considered are highly exothermic; the values of $\Delta_{\mathrm{r}} H^{\circ}(0)$ vary from -374 to $-4499 \mathrm{~kJ} \mathrm{~mol}^{-1}$. Generally, the biggest amount of energy released through detonation channels with the formation of $\mathrm{CO}_{2}, \mathrm{~N}_{2}, \mathrm{HF} / \mathrm{F}_{2}$, and the smallest enthalpy of detonation is observed for the reactions $\mathrm{A} 4-\mathrm{G} 4$ with the $\mathrm{C}, \mathrm{CO}$, and $\mathrm{O}_{2}$ products. Clearly seen that fluorination of the bridged trinitromethyl azo triazole alters the heat effect. That is in accordance with findings by other researchers $[2,19,22,23]$ that most exothermic reactions relate to the hydrogen fluoride being formed among the products. If compare the enthalpies of most exothermic detonation reactions, i.e. $A 1-G 1$, the values of $\Delta_{\mathrm{r}} H^{\circ}(0)$ become more negative due to the azo-chain fluorination in the absence of triazole ring fluorination, from -3367 (A1) up to -4216 (B1) and $-3923 \mathrm{~kJ} \mathrm{~mol}^{-1}$ (D1); whereas fluorination of the rings brings to lower heat effect in 
Table 1 Selected optimized geometrical parameters of non-fluorinated $(A)$ and designed fluorinated bridged triazole derivatives $(B-G)$

\begin{tabular}{lllllll}
\hline Molecule & $\mathrm{R}_{1,2,3}(\mathrm{~N}-\mathrm{N})$ & $\mathrm{R}_{1,2}(\mathrm{~N}-\mathrm{F})$ & $\mathrm{R}_{1,2}(\mathrm{C}-\mathrm{F})$ & $\mathrm{a}_{1,2}(\mathrm{~N}-\mathrm{C}-\mathrm{N})$ & $\chi(\mathrm{N}-\mathrm{N}-\mathrm{N}-\mathrm{N})$ & $\phi_{1,2}(\mathrm{C}-\mathrm{N}-\mathrm{N}-\mathrm{C})$ \\
\hline $\mathrm{A}$ & $1.368,1.246,1.368$ & & & $110.0,110.0$ & 180.0 & $180.0,180.0$ \\
$\mathrm{~B}$ & $1.390,1.464,1.295$ & 1.420 & & $110.0,110.0$ & 176.0 & $176.0,179.0$ \\
$\mathrm{C}$ & $1.371,1.246,1.365$ & & 1.304 & $112.0,110.0$ & 179.0 & $175.0,176.0$ \\
$\mathrm{D}$ & $1.377,1.506,1.376$ & $1.414,1.414$ & & $109.0,109.0$ & 174.0 & $173.0,175.0$ \\
$\mathrm{E}$ & $1.370,1.246,1.370$ & & $1.304,1.304$ & $112.0,112.0$ & 180.0 & $180.0,180.0$ \\
$\mathrm{~F}$ & $1.376,1.511,1.376$ & $1.414,1.414$ & 1.303 & $112.0,110.0$ & 173.0 & $175.0,173.0$ \\
$\mathrm{G}$ & $1.380,1.423,1.379$ & $1.417,1.420$ & 1.302 & $112.0,112.0$ & 154.0 & $78.0,172.0$ \\
\hline
\end{tabular}

Bond lengths $(\AA)$, bond angles $\left(^{\circ}\right)$ and dihedral angles $\left(^{\circ}\right)$

$\mathrm{R}_{1,2,3}(\mathrm{~N}-\mathrm{N})$ are $\mathrm{R}_{1}\left(\mathrm{~N}_{3}-\mathrm{N}_{4}\right), \mathrm{R}_{2}\left(\mathrm{~N}_{4}-\mathrm{N}_{5}\right)$ and $\mathrm{R}_{3}\left(\mathrm{~N}_{5}-\mathrm{N}_{6}\right)$

$\mathrm{R}_{1,2}(\mathrm{C}-\mathrm{F})$ are left and right side, equivalent bonds

$\mathrm{R}_{1,2}(\mathrm{~N}-\mathrm{F})$ are the bond lengths on the azo group $\mathrm{R}_{1}\left(\mathrm{~N}_{4}-\mathrm{F}\right), \mathrm{R}_{2}\left(\mathrm{~N}_{5}-\mathrm{F}\right)$

$\mathrm{a}_{1,2}(\mathrm{~N}-\mathrm{C}-\mathrm{N})$ are the bond angles $\mathrm{a}_{1}\left(\mathrm{~N}_{2}-\mathrm{C}_{2}-\mathrm{N}_{3}\right)$ and $\mathrm{a}_{2}\left(\mathrm{~N}_{6}-\mathrm{C}_{3}-\mathrm{N}_{7}\right)$ in the left and right triazole rings, respectively

$\varphi_{1,2}(\mathrm{C}-\mathrm{N}-\mathrm{N}-\mathrm{C})$ are the dihedral angles $\varphi_{1}\left(\mathrm{C}_{1}-\mathrm{N}_{3}-\mathrm{N}_{6}-\mathrm{C}_{4}\right)$ and $\varphi_{2}\left(\mathrm{C}_{2}-\mathrm{N}_{4}-\mathrm{N}_{5}-\mathrm{C}_{3}\right)$ between two azo rings reactions $\mathrm{C} 1, \mathrm{E} 1-\mathrm{G} 1$ than for the non-fluorinated original compound (A1).

The enthalpies of most exothermic detonation reactions (A1-G1) and combustion reactions (A5-G5) are shown in Fig. 4.

A symbatic behaviour is well seen for the enthalpies of detonation and combustion reactions with maxima for $E$ and $G$ and minima for $B$ and $D$. Worth to note, for the $A$ and $B$ molecules, combustion is more exothermic compared to detonation. For both types of reactions, the $\Delta_{\mathrm{r}} \mathrm{H}^{\circ}(0)$ becomes more negative as the fluorine atoms are attached on the hydrazine chain and less negative under ring fluorination. Among all compounds, the molecules $\mathrm{B}$ and $D$ with one and two $F$ atoms attached to the azo-chain have most negative enthalpies of the reactions.

The computed enthalpies of the reactions $\Delta_{\mathrm{r}} H^{\circ}(0)$ and enthalpy increments $\Delta_{\mathrm{r}}\left[H^{\circ}(298)-H^{\circ}(0)\right]$ have been used to obtain enthalpies of formation $\Delta_{\mathrm{f}} H^{\circ}(0)$ and $\Delta_{\mathrm{f}} H^{\circ}(298)$ of the gaseous species according to Eqs. (3), (4) and (5). The averaged values of enthalpies of formations over all five reactions have been calculated for each compound, the uncertainties are estimated as standard deviations (Table 2). The thermodynamic properties of individual gaseous species A-G, enthalpies of formation $\Delta_{\mathrm{f}} H^{\circ}(298)$ and entropies $S^{\circ}(298)$, are displayed in Fig. 5.

It is observed generally that the consequent addition of fluorine atoms to the molecule from $A$ to $G$ results in irregular change of both characteristics. The position of the $\mathrm{F}$ atoms influences the alteration; the hydrazine chain fluorination brings to a larger change of both $\Delta_{\mathrm{f}} \mathrm{H}^{\circ}(\mathrm{g}, 298)$ and $S^{\circ}(g, 298)$ compared to the triazole rings fluorination. The most distorted geometry of the G compound which contains four $\mathrm{F}$ atoms, two on the hydrazine chain and two on the rings, evidently promotes the greatest entropy among all species.
Temperature dependences of the TDF for different decomposition reactions were also considered. For most exothermic detonation reactions (A1-G1), the entropies $\Delta_{\mathrm{r}} S^{\circ}(T)$ and Gibbs free energies $\Delta_{\mathrm{r}} G^{\circ}(T)$ over a broad temperature range are presented in Fig. 6 . The entropies of all reactions are positive and rather high (Fig. 6a); at room temperature the values of $\Delta_{\mathrm{r}} S^{\circ}(298)$ range from $\sim 1980$ (D1) to $2150 \mathrm{~J} \mathrm{~mol}^{-1} \mathrm{~K}^{-1}$ (F1 and G1); which is apparently attributed to the greater number of detonation products, $15 \mathrm{~mol}$ of products formed from one mole of reactant. There are two groups of curves distinguished; the first one of lower $\Delta_{r} S^{\circ}(T)$ combines three decay reactions, of the original (A1) and triazole rings fluorinated compounds $(C 1, E 1)$. The second one of higher $\Delta_{\mathrm{r}} S^{\circ}(T)$ combines the reactions of the rest four species, each of them having $F$ atoms at the hydrazine chain. In both groups, the entropies $\Delta_{\mathrm{r}} S^{\circ}(T)$ slightly decrease by $\sim 100 \mathrm{~J} \mathrm{~mol}^{-1} \mathrm{~K}^{-1}$ subject to temperature increase to $1000 \mathrm{~K}$.

The temperature dependences of Gibbs energies of the reactions have been computed using Eq. (8), and the results are presented in Fig. $6 \mathrm{~b}$. The values of $\Delta_{\mathrm{r}} G^{\circ}(T)$ are negative attributing to exothermicity of the reactions and positive $\Delta_{\mathrm{r}} S^{\circ}(T)$, and keep on descending with temperature rise depending on the number and position of attachment of fluorine atoms. Therefore all reactions are predicted to be spontaneous; moreover, only hydrazine chain fluorinated compounds ( $B$ and $D$ ) show higher numerical values of Gibbs energy compared to the ring fluorinated (C, E, F and $G$ ) and non-fluorinated (A) species.

\subsection{Energetic properties}

Energetic properties include several characteristics of the materials which signify strength, stability and ability to detonate. These properties, enthalpies of formation of 
Fig. 2 Computed infrared spectra of non-fluorinated (A) and fluorinated $(B-G)$ bridged triazole derivatives
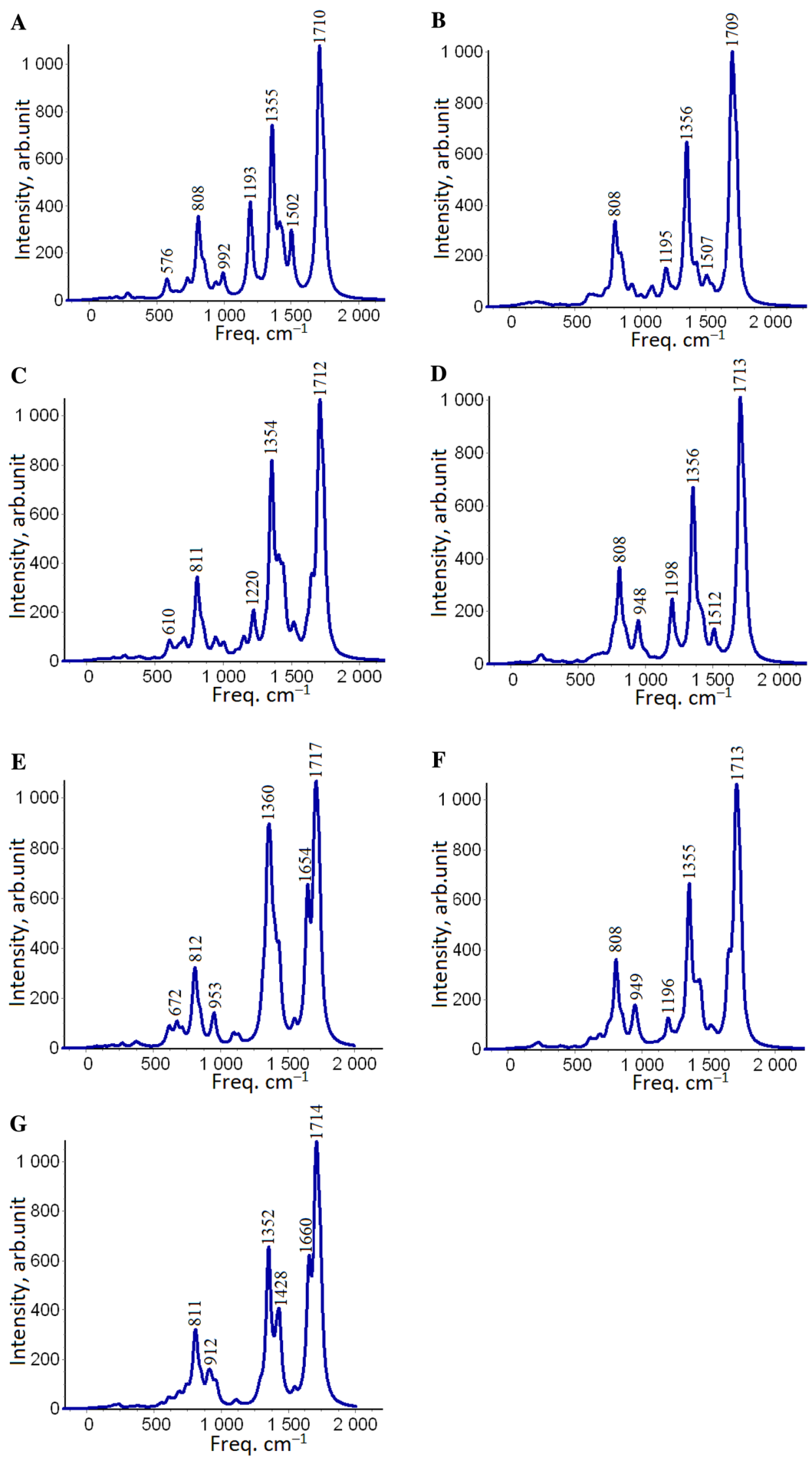


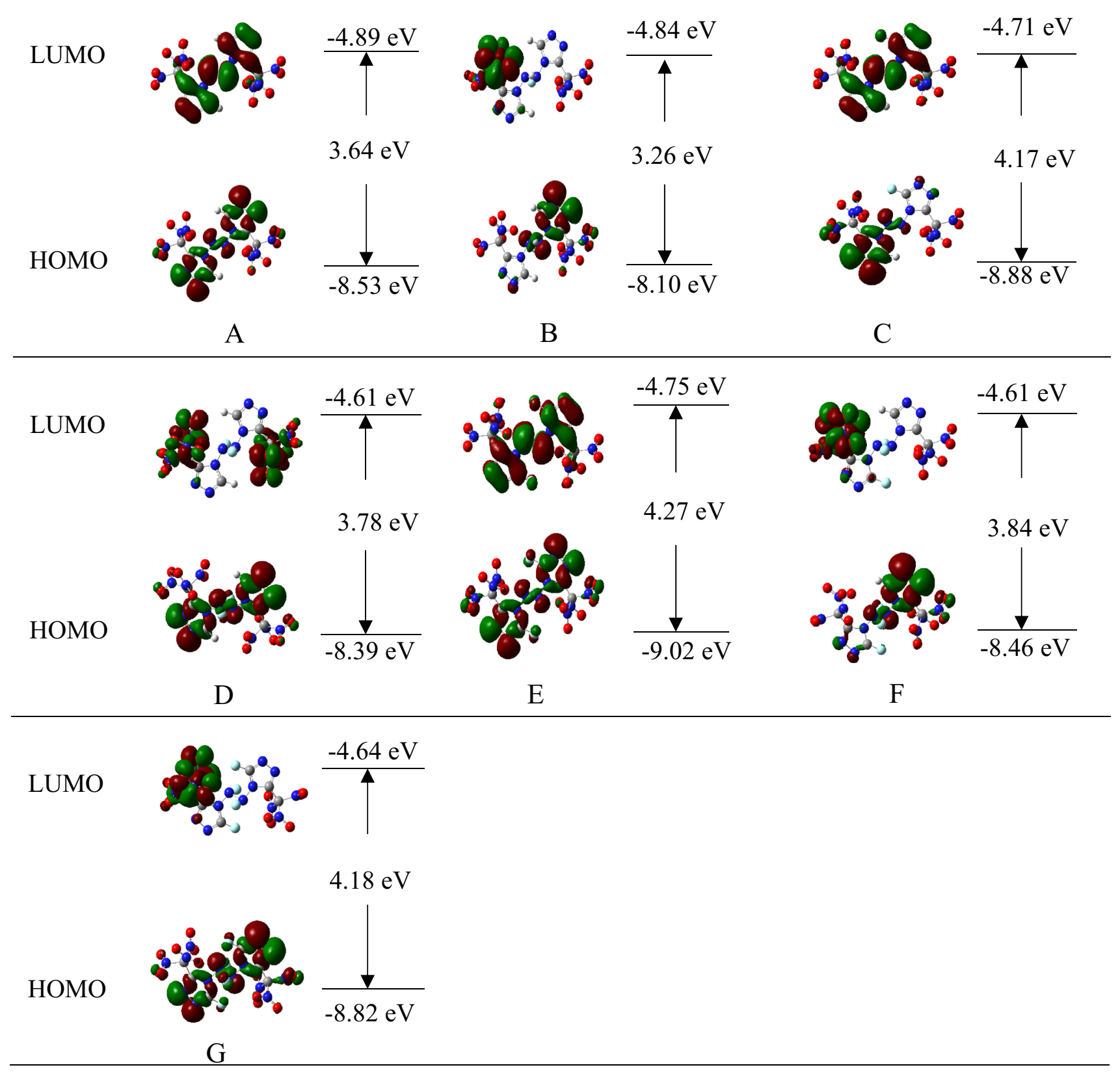

Fig. 3 Graphical representation of HOMO and LUMO isosurfaces, energies, and energy gaps of molecules A-G

solid compounds $\Delta_{\mathrm{f}} H^{\circ}(c, 298)$, molecular density $\rho_{\text {mol }}$, the heat of detonation $\mathrm{Q}$, detonation velocity $\mathrm{VD}$ and pressure $P D$, impact sensitivity $h_{50 \%}$, and coefficient of oxidation $a$, calculated by using Eqs. (9)-(16) for seven compounds A-G are presented in Table 3; for comparison, two conventional explosives (RDX and HMX) and four nearly related energetic compounds reported earlier in literature $[5,6,32,34$, $47,48]$ are also considered.

The enthalpies of sublimation $\Delta_{\text {sub }} H^{\circ}(298)$ of the compounds A-G have been evaluated using Eq. (7) and found to be close from one molecule to another within the range of 192 to $196 \mathrm{~kJ} \mathrm{~mol}^{-1}$. Based on the $\Delta_{\text {sub }} H^{\circ}(298)$ and enthalpies of formation of gaseous species $\Delta_{\mathrm{f}} H^{\circ}(\mathrm{g}$, 298), the enthalpies of formation of solid compounds A-G $\Delta_{f} H^{\circ}(c, 298)$ have been obtained by Eq. (6). For all solid compounds $A-G$, the enthalpies $\Delta_{f} H^{\circ}(c, 298)$ are positive, from $\sim 500$ to $900 \mathrm{~kJ} \mathrm{~mol}^{-1}$ and change depending on the position attachment of fluorine atoms (the trend is similar to that for gaseous species in Fig. 5a). The calculated enthalpies of formation for the compounds A-G are compared to nearly related explosives reported earlier in Table 3. Due to fluorination, the enthalpies of 
Table 2 Thermodynamic characteristics of gas phase reactions and enthalpies of formation of gaseous compounds, all values in kJ mol ${ }^{-1}$

\begin{tabular}{|c|c|c|c|c|c|c|c|}
\hline & Equation of chemical reaction & $-\Delta_{\mathrm{r}} E$ & $-\Delta_{\mathrm{r}} \mathrm{ZPVE}$ & $-\Delta_{\mathrm{r}} H^{\circ}(0)$ & $\Delta_{\mathrm{r}}\left[H^{\circ}(298)-H^{\circ}(0)\right]$ & $\Delta_{\mathrm{f}} H^{\circ}(0)$ & $\overline{\Delta_{\mathrm{f}} H^{\circ}(298)}$ \\
\hline $\mathrm{A} 1$ & $\mathrm{C}_{6} \mathrm{H}_{2} \mathrm{~N}_{14} \mathrm{O}_{12}=\mathrm{CO}+5 \mathrm{CO}_{2}+7 \mathrm{~N}_{2}+\mathrm{H}_{2} \mathrm{O}$ & 3237.7 & 129.0 & 3366.6 & 47.11 & 1048.2 & 1095.3 \\
\hline $\mathrm{A} 2$ & $\mathrm{C}_{6} \mathrm{H}_{2} \mathrm{~N}_{14} \mathrm{O}_{12}=0.5 \mathrm{C}+5.5 \mathrm{CO}_{2}+7 \mathrm{~N}_{2}+\mathrm{H}_{2} \mathrm{O}$ & 2897.3 & 126.9 & 3024.2 & 46.01 & 978.5 & 1024.5 \\
\hline $\mathrm{A} 3$ & $\mathrm{C}_{6} \mathrm{H}_{2} \mathrm{~N}_{14} \mathrm{O}_{12}=6 \mathrm{CO}+7 \mathrm{~N}_{2}+\mathrm{H}_{2} \mathrm{O}+2.5 \mathrm{O}_{2}$ & 1758.8 & 191.8 & 1950.6 & 69.17 & 1028.8 & 1098.0 \\
\hline A4 & $\mathrm{C}_{6} \mathrm{H}_{2} \mathrm{~N}_{14} \mathrm{O}_{12}=5 \mathrm{CO}+\mathrm{C}+7 \mathrm{~N}_{2}+\mathrm{H}_{2} \mathrm{O}+3 \mathrm{O}_{2}$ & 782.3 & 200.2 & 982.4 & 71.38 & 885.7 & 957.0 \\
\hline A5 & $\mathrm{C}_{6} \mathrm{H}_{2} \mathrm{~N}_{14} \mathrm{O}_{12}+0.5 \mathrm{O}_{2}=6 \mathrm{CO}_{2}+7 \mathrm{~N}_{2}+\mathrm{H}_{2} \mathrm{O}$ & 3533.4 & 116.4 & 3649.8 & 42.70 & 1052.0 & 1094.7 \\
\hline \multicolumn{6}{|c|}{ Average $\Delta_{\mathrm{f}} H^{\circ}(\mathrm{A}, \mathrm{g})$} & $999 \pm 70$ & $1054 \pm 62$ \\
\hline B1 & $\mathrm{C}_{6} \mathrm{H}_{3} \mathrm{~N}_{14} \mathrm{O}_{12} \mathrm{~F}=\mathrm{CO}+5 \mathrm{CO}_{2}+7 \mathrm{~N}_{2}+\mathrm{H}_{2} \mathrm{O}+\mathrm{HF}$ & 4072.5 & 143.6 & 4216.1 & 52.3 & 994.3 & 1046.6 \\
\hline B2 & $\mathrm{C}_{6} \mathrm{H}_{3} \mathrm{~N}_{14} \mathrm{O}_{12} \mathrm{~F}=0.5 \mathrm{C}+5.5 \mathrm{CO}_{2}+7 \mathrm{~N}_{2}+\mathrm{H}_{2} \mathrm{O}+\mathrm{HF}$ & 3732.1 & 141.5 & 3873.6 & 55.4 & 924.6 & 980.0 \\
\hline B3 & $\mathrm{C}_{6} \mathrm{H}_{3} \mathrm{~N}_{14} \mathrm{O}_{12} \mathrm{~F}=6 \mathrm{CO}+7 \mathrm{~N}_{2}+\mathrm{H}_{2} \mathrm{O}+2.5 \mathrm{O}_{2}+\mathrm{HF}$ & 2593.6 & 206.5 & 2800.0 & 74.4 & 974.9 & 1049.3 \\
\hline B4 & $\mathrm{C}_{6} \mathrm{H}_{3} \mathrm{~N}_{14} \mathrm{O}_{12} \mathrm{~F}=5 \mathrm{CO}+\mathrm{C}+7 \mathrm{~N}_{2}+\mathrm{H}_{2} \mathrm{O}+3 \mathrm{O}_{2}+\mathrm{HF}$ & 1617.1 & 214.8 & 1831.9 & 76.6 & 831.8 & 908.3 \\
\hline B5 & $\mathrm{C}_{6} \mathrm{H}_{3} \mathrm{~N}_{14} \mathrm{O}_{12} \mathrm{~F}+0.5 \mathrm{O}_{2}=6 \mathrm{CO}_{2}+7 \mathrm{~N}_{2}+\mathrm{H}_{2} \mathrm{O}+\mathrm{HF}$ & 4368.2 & 131.0 & 4499.3 & 52.5 & 998.1 & 1050.6 \\
\hline \multicolumn{6}{|c|}{ Average $\Delta_{\mathrm{f}} H^{\circ}(\mathrm{B}, \mathrm{g})$} & $945 \pm 70$ & $1007 \pm 63$ \\
\hline $\mathrm{C} 1$ & $\mathrm{C}_{6} \mathrm{H}_{1} \mathrm{~N}_{14} \mathrm{O}_{12} \mathrm{~F}=6 \mathrm{CO}_{2}+7 \mathrm{~N}_{2}+\mathrm{HF}$ & 3414.0 & 121.8 & 3535.8 & 43.4 & 903.6 & 947.0 \\
\hline $\mathrm{C} 2$ & $\mathrm{C}_{6} \mathrm{H}_{1} \mathrm{~N}_{14} \mathrm{O}_{12} \mathrm{~F}=0.5 \mathrm{CO}+5.5 \mathrm{CO}_{2}+7 \mathrm{~N}_{2}+0.5 \mathrm{H}_{2} \mathrm{O}+0.5 \mathrm{~F}_{2}$ & 3109.0 & 124.1 & 3233.1 & 48.4 & 894.4 & 942.8 \\
\hline $\mathrm{C} 3$ & $\mathrm{C}_{6} \mathrm{H}_{1} \mathrm{~N}_{14} \mathrm{O}_{12} \mathrm{~F}=6 \mathrm{CO}+7 \mathrm{~N}_{2}+3 \mathrm{O}_{2}+\mathrm{HF}$ & 1639.3 & 197.2 & 1836.5 & 69.9 & 880.4 & 950.3 \\
\hline $\mathrm{C} 4$ & $\mathrm{C}_{6} \mathrm{H}_{1} \mathrm{~N}_{14} \mathrm{O}_{12} \mathrm{~F}=5 \mathrm{CO}+\mathrm{C}+7 \mathrm{~N}_{2}+0.5 \mathrm{H}_{2} \mathrm{O}+3.25 \mathrm{O}_{2}+0.5 \mathrm{~F}_{2}$ & 505.7 & 201.6 & 707.3 & 70.7 & 730.0 & 800.7 \\
\hline C5 & $\mathrm{C}_{6} \mathrm{H}_{1} \mathrm{~N}_{14} \mathrm{O}_{12} \mathrm{~F}+0.25 \mathrm{O}_{2}=6 \mathrm{CO}_{2}+7 \mathrm{~N}_{2}+0.5 \mathrm{H}_{2} \mathrm{O}+0.5 \mathrm{~F}_{2}$ & 3256.9 & 117.8 & 3374.7 & 42.0 & 896.4 & 933.9 \\
\hline \multicolumn{6}{|c|}{ Average $\Delta_{\mathrm{f}} H^{\circ}(\mathrm{C}, \mathrm{g})$} & $861 \pm 74$ & $915 \pm 64$ \\
\hline D1 & $\mathrm{C}_{6} \mathrm{H}_{2} \mathrm{~N}_{14} \mathrm{O}_{12} \mathrm{~F}_{2}=6 \mathrm{CO}_{2}+7 \mathrm{~N}_{2}+2 \mathrm{HF}$ & 3791.9 & 130.6 & 3922.6 & 48.4 & 1017.2 & 1065.6 \\
\hline $\mathrm{D} 2$ & $\mathrm{C}_{6} \mathrm{H}_{2} \mathrm{~N}_{14} \mathrm{O}_{12} \mathrm{~F}_{2}=0.5 \mathrm{C}+5.5 \mathrm{CO}_{2}+7 \mathrm{~N}_{2}+\mathrm{H}_{2} \mathrm{O}+\mathrm{F}_{2}$ & 2841.5 & 133.2 & 2974.8 & 53.1 & 929.1 & 982.3 \\
\hline D3 & $\mathrm{C}_{6} \mathrm{H}_{2} \mathrm{~N}_{14} \mathrm{O}_{12} \mathrm{~F}_{2}=6 \mathrm{CO}+7 \mathrm{~N}_{2}+3 \mathrm{O}_{2}+\mathrm{HF}$ & 2017.2 & 206.1 & 2223.3 & 74.9 & 994.0 & 1068.8 \\
\hline D4 & $\mathrm{C}_{6} \mathrm{H}_{2} \mathrm{~N}_{14} \mathrm{O}_{12} \mathrm{~F}_{2}=5 \mathrm{CO}+\mathrm{C}+7 \mathrm{~N}_{2}+3.5 \mathrm{O}_{2}+2 \mathrm{HF}$ & 1040.7 & 214.4 & 1255.2 & 77.1 & 850.8 & 927.9 \\
\hline D5 & $\mathrm{C}_{6} \mathrm{H}_{2} \mathrm{~N}_{14} \mathrm{O}_{12} \mathrm{~F}_{2}+0.5 \mathrm{O}_{2}=6 \mathrm{CO}_{2}+7 \mathrm{~N}_{2}+\mathrm{H}_{2} \mathrm{O}+\mathrm{F}_{2}$ & 3477.7 & 122.8 & 3600.5 & 50.2 & 1002.7 & 1052.9 \\
\hline \multicolumn{6}{|c|}{ Average $\Delta_{\mathrm{f}} H^{\circ}(\mathrm{D}, \mathrm{g})$} & $959 \pm 69$ & $1020 \pm 62$ \\
\hline E1 & $\mathrm{C}_{6} \mathrm{~N}_{14} \mathrm{O}_{12} \mathrm{~F}_{2}=6 \mathrm{CO}_{2}+7 \mathrm{~N}_{2}+\mathrm{F}_{2}$ & 2980.0 & 119.2 & 3099.2 & 45.8 & 740.4 & 786.2 \\
\hline E2 & $\mathrm{C}_{6} \mathrm{~N}_{14} \mathrm{O}_{12} \mathrm{~F}_{2}=0.5 \mathrm{C}+5.5 \mathrm{CO}_{2}+7 \mathrm{~N}_{2}+0.5 \mathrm{O}_{2}+\mathrm{F}_{2}$ & 2343.9 & 129.6 & 2473.6 & 48.7 & 666.8 & 715.6 \\
\hline E3 & $\mathrm{C}_{6} \mathrm{~N}_{14} \mathrm{O}_{12} \mathrm{~F}_{2}=6 \mathrm{CO}+7 \mathrm{~N}_{2}+3 \mathrm{O}_{2}+\mathrm{F}_{2}$ & 1205.4 & 194.6 & 1400.0 & 67.7 & 717.1 & 784.8 \\
\hline E4 & $\mathrm{C}_{6} \mathrm{~N}_{14} \mathrm{O}_{12} \mathrm{~F}_{2}=5 \mathrm{CO}+\mathrm{C}+7 \mathrm{~N}_{2}+3.5 \mathrm{O}_{2}+\mathrm{F}_{2}$ & 228.9 & 203.0 & 431.8 & 69.9 & 574.0 & 643.9 \\
\hline E5 & $\mathrm{C}_{6} \mathrm{~N}_{14} \mathrm{O}_{12} \mathrm{~F}_{2}+0.5 \mathrm{O}_{2}=6 \mathrm{CO}_{2}+7 \mathrm{~N}_{2}+\mathrm{F}_{2} \mathrm{O}$ & 2953.3 & 116.1 & 3069.3 & 43.6 & 737.2 & 780.8 \\
\hline \multicolumn{6}{|c|}{ Average $\Delta_{\mathrm{f}} H^{\circ}(\mathrm{E}, \mathrm{g})$} & $687 \pm 70$ & $742 \pm 63$ \\
\hline $\mathrm{F} 1$ & $\mathrm{C}_{6} \mathrm{H}_{1} \mathrm{~N}_{14} \mathrm{O}_{12} \mathrm{~F}_{3}=6 \mathrm{CO}_{2}+7 \mathrm{~N}_{2}+\mathrm{HF}+\mathrm{F}_{2}$ & 3345.5 & 128.6 & 3474.1 & 46.4 & 841.9 & 888.3 \\
\hline $\mathrm{F} 2$ & $\mathrm{C}_{6} \mathrm{H}_{1} \mathrm{~N}_{14} \mathrm{O}_{12} \mathrm{~F}_{3}=0.5 \mathrm{CO}+5.5 \mathrm{CO}_{2}+7 \mathrm{~N}_{2}+0.5 \mathrm{H}_{2} \mathrm{O}+1.5 \mathrm{~F}_{2}$ & 3040.5 & 131.0 & 3171.4 & 47.2 & 832.8 & 794.1 \\
\hline F3 & $\mathrm{C}_{6} \mathrm{H}_{1} \mathrm{~N}_{14} \mathrm{O}_{12} \mathrm{~F}_{3}=6 \mathrm{CO}+7 \mathrm{~N}_{2}+3 \mathrm{O}_{2}+\mathrm{HF}+\mathrm{F}_{2}$ & 1570.8 & 204.0 & 1774.8 & 72.8 & 818.7 & 891.6 \\
\hline $\mathrm{F} 4$ & $\mathrm{C}_{6} \mathrm{H}_{1} \mathrm{~N}_{14} \mathrm{O}_{12} \mathrm{~F}_{3}=5 \mathrm{CO}+\mathrm{C}+7 \mathrm{~N}_{2}+0.5 \mathrm{H}_{2} \mathrm{O}+3.25 \mathrm{O}_{2}+1.5 \mathrm{~F}_{2}$ & 437.2 & 208.4 & 645.6 & 73.6 & 668.3 & 742.0 \\
\hline F5 & $\mathrm{C}_{6} \mathrm{H}_{1} \mathrm{~N}_{14} \mathrm{O}_{12} \mathrm{~F}_{3}+0.25 \mathrm{O}_{2}=6 \mathrm{CO}_{2}+7 \mathrm{~N}_{2}+0.5 \mathrm{H}_{2} \mathrm{O}+1.5 \mathrm{~F}_{2}$ & 3188.4 & 124.7 & 3313.0 & 45.0 & 834.7 & 769.9 \\
\hline \multicolumn{6}{|c|}{ Average $\Delta_{\mathrm{f}} H^{\circ}(\mathrm{F}, \mathrm{g})$} & $799 \pm 74$ & $817 \pm 69$ \\
\hline G1 & $\mathrm{C}_{6} \mathrm{~N}_{14} \mathrm{O}_{12} \mathrm{~F}_{4}=6 \mathrm{CO}_{2}+7 \mathrm{~N}_{2}+2 \mathrm{~F}_{2}$ & 2915.7 & 126.0 & 3041.8 & 48.9 & 682.9 & 731.8 \\
\hline G2 & $\mathrm{C}_{6} \mathrm{~N}_{14} \mathrm{O}_{12} \mathrm{~F}_{4}=0.5 \mathrm{C}+5.5 \mathrm{CO}_{2}+7 \mathrm{~N}_{2}+0.5 \mathrm{O}_{2}+2 \mathrm{~F}_{2}$ & 2279.6 & 136.5 & 2416.1 & 51.9 & 609.4 & 661.3 \\
\hline G3 & $\mathrm{C}_{6} \mathrm{~N}_{14} \mathrm{O}_{12} \mathrm{~F}_{4}=6 \mathrm{CO}+7 \mathrm{~N}_{2}+3 \mathrm{O}_{2}+2 \mathrm{~F}_{2}$ & 1141.1 & 201.5 & 1342.5 & 70.8 & 659.7 & 730.5 \\
\hline G4 & $\mathrm{C}_{6} \mathrm{~N}_{14} \mathrm{O}_{12} \mathrm{~F}_{4}=5 \mathrm{CO}+\mathrm{C}+7 \mathrm{~N}_{2}+3.5 \mathrm{O}_{2}+2 \mathrm{~F}_{2}$ & 164.6 & 209.8 & 374.4 & 73.0 & 516.5 & 589.5 \\
\hline G5 & $\mathrm{C}_{6} \mathrm{~N}_{14} \mathrm{O}_{12} \mathrm{~F}_{4}+\mathrm{O}_{2}=6 \mathrm{CO}_{2}+7 \mathrm{~N}_{2}+2 \mathrm{~F}_{2} \mathrm{O}$ & 2862.2 & 119.8 & 2982.0 & 44.4 & 676.6 & 721.1 \\
\hline \multicolumn{6}{|c|}{ Average $\Delta_{\mathrm{f}} H^{\circ}(\mathrm{G}, \mathrm{g})$} & $629 \pm 69$ & $687 \pm 62$ \\
\hline
\end{tabular}

formation of all designed compounds are much higher than those of common explosives, $79.0 \mathrm{~kJ} \mathrm{~mol}^{-1}$ (RDX) and $102.4 \mathrm{~kJ} \mathrm{~mol}^{-1}$ (HMX).

Density is one of the significant properties the material must possess as it accounts for its strength; the higher the density, the stronger the material and hence more energy the material will produce upon detonation. It is observed that for all compounds considered in this study the density increases as the number of fluorine atoms is increased. The range of densities is from $1.96 \mathrm{~g} \mathrm{~cm}^{-3}$ for the non-fluorinated molecule $A$ to $2.14 \mathrm{~g} \mathrm{~cm}^{-3}$ for a highly fluorinated $G$. The increase 


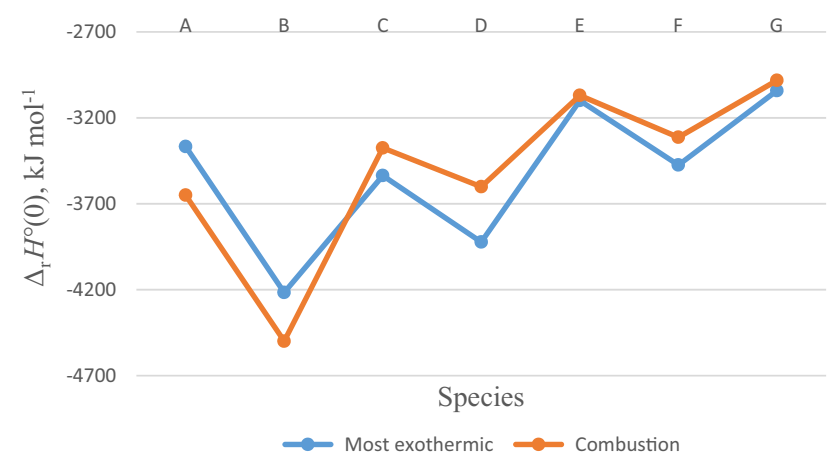

Fig. 4 Enthalpies of gaseous detonation (A1-G1) and combustion (A5-G5) reactions versus molecular species

in densities can be justified by high mass of fluorine atom with small effect on the volume of the molecule and strong $\pi$-bonding between the triazole rings and azo/hydrazine group resulting into strong packing. The values of $\rho_{\text {mol }}$ for the A-G species are comparable to those for nearly related materials reported in the literature, which are in the range $1.80-2.04 \mathrm{~g} \mathrm{~cm}^{-3}$ (Table 3 ).

Detonation heat is a measure of the material strength and stability as it signifies the amount of energy released as the material detonates. The performance of the material is estimated depending on the value of $Q$; the higher the value of $Q$, the greater the materials performance. The detonation heats have been computed using Eq. (14) for most exothermic detonation processes $\mathrm{A} 1-\mathrm{G} 1$ where the enthalpies of formation of solid reactants $\Delta_{f} H^{\circ}(c, 298)$ have been taken into account. Among all designed compounds, $B, C$ and $D$ have higher detonation heat $Q$ greater than $1600 \mathrm{cal} \mathrm{g}^{-1}$. This may be due to hydrazine chain fluorination as well as sufficient number of hydrogen atoms in a molecule for complete detonation. Still, these $Q$ values are close to those of reference and original compounds. Worth to note that fluorination of the triazole rings does not bring the elevation of the detonation heat.
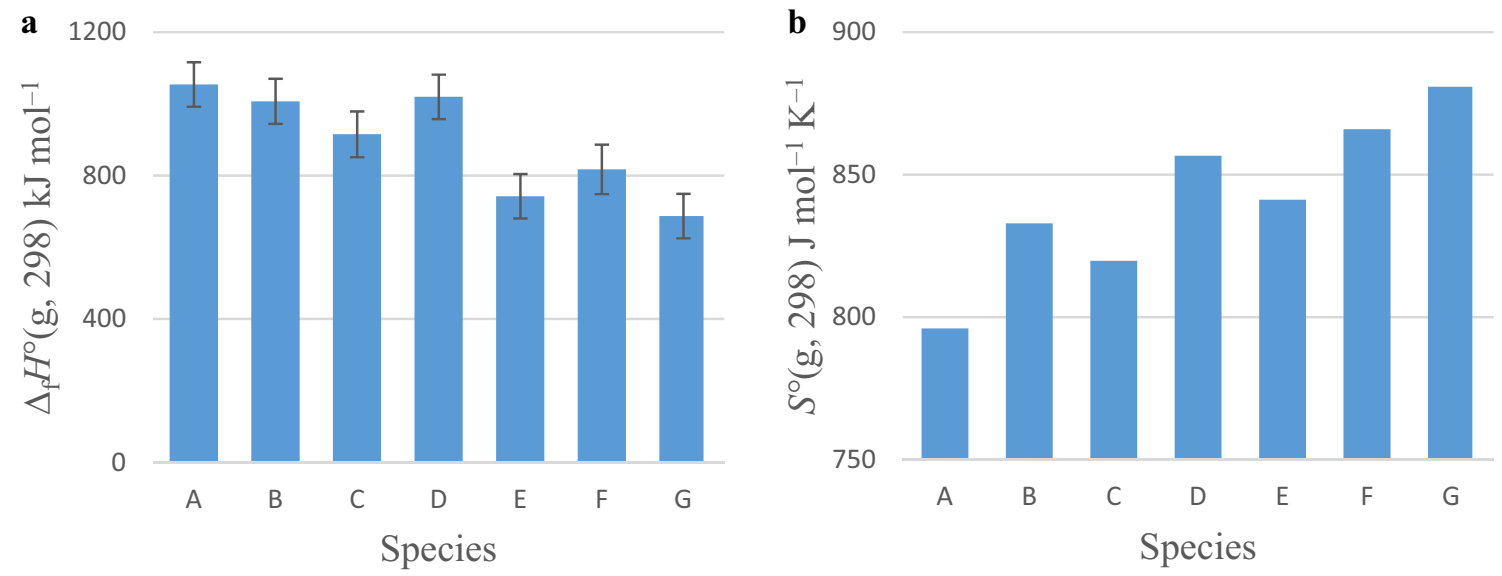

Fig. 5 Thermodynamic characteristics of gaseous species A-G: a enthalpies of formation $\Delta_{\mathrm{f}} H^{\circ}(\mathrm{g}, 298) ; \mathbf{b}$ entropies $S^{\circ}(\mathrm{g}, 298)$
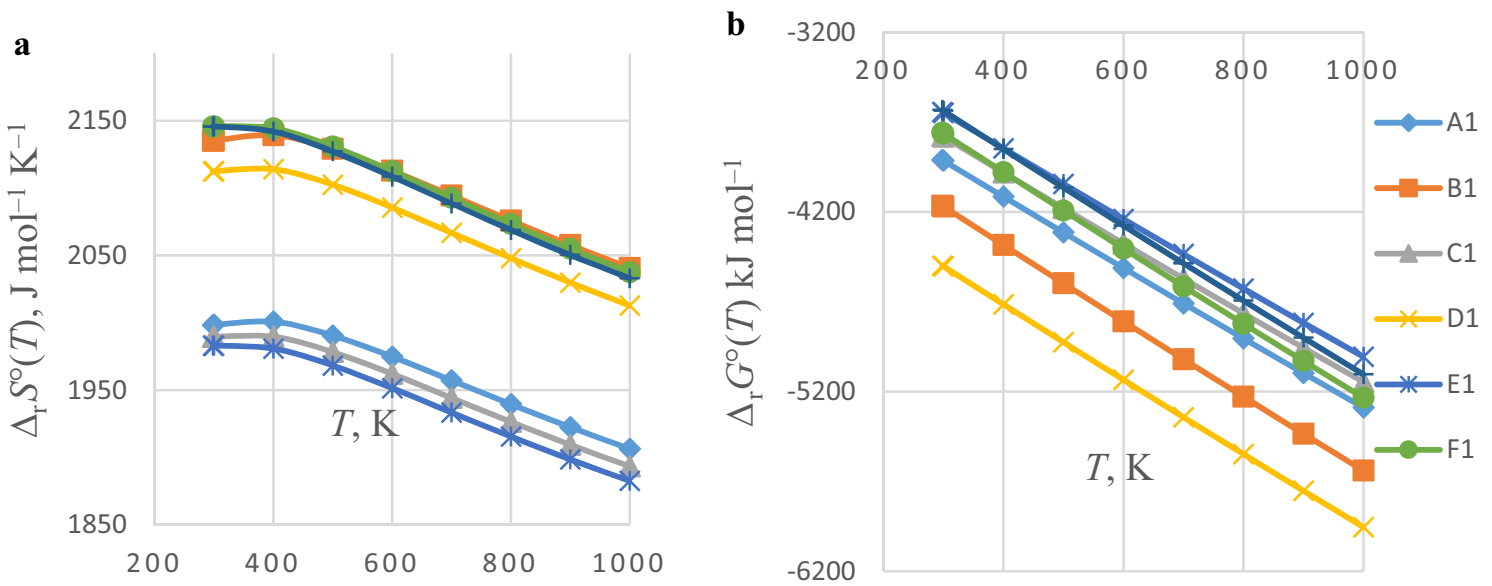

Fig. 6 Temperature dependences of $\mathbf{a}$ entropies $\Delta_{\mathrm{r}} S^{\circ}(T)$ and $\mathbf{b}$ Gibbs free energies $\Delta_{\mathrm{r}} G^{\circ}(T)$ of most exothermic detonation reactions (A1-G1) 
Table 3 The energetic properties of the compounds $A-G$, together with related energetic compounds reported in literature

\begin{tabular}{lllllllll}
\hline $\begin{array}{l}\text { Species/ } \\
\text { Refs }\end{array}$ & Compound & $\begin{array}{l}\Delta_{\mathrm{f}} \mathrm{H}^{\circ}(\mathrm{c}, 298) \\
\mathrm{kJ} \mathrm{mol}^{-1}\end{array}$ & $\begin{array}{l}\rho_{\mathrm{mol}} \\
\mathrm{g} \mathrm{cm}^{-3}\end{array}$ & $\begin{array}{l}\mathrm{Q} \\
\mathrm{cal} \mathrm{g}^{-1}\end{array}$ & $\begin{array}{l}\mathrm{VD} \\
\mathrm{km} \mathrm{s}^{-1}\end{array}$ & $\begin{array}{l}\mathrm{PD} \\
\mathrm{GPa}\end{array}$ & $\begin{array}{l}\mathrm{h}_{50 \%} \\
\mathrm{~cm}\end{array}$ & $\mathrm{a}$ \\
\hline $\mathrm{A}$ & $\mathrm{C}_{6} \mathrm{H}_{2} \mathrm{~N}_{14} \mathrm{O}_{12}$ & $862 \pm 62$ & 1.96 & 1646 & 9.5 & 42.3 & 30.8 & 0.92 \\
$\mathrm{~B}$ & $\mathrm{C}_{6} \mathrm{H}_{3} \mathrm{~N}_{14} \mathrm{O}_{12} \mathrm{~F}$ & $811 \pm 63$ & 1.98 & 1688 & 9.7 & 44.3 & 32.0 & 0.93 \\
$\mathrm{C}$ & $\mathrm{C}_{6} \mathrm{H}_{1} \mathrm{~N}_{14} \mathrm{O}_{12} \mathrm{~F}$ & $724 \pm 64$ & 2.01 & 1672 & 9.6 & 44.0 & 30.1 & 1.00 \\
D & $\mathrm{C}_{6} \mathrm{H}_{2} \mathrm{~N}_{14} \mathrm{O}_{12} \mathrm{~F}_{2}$ & $868 \pm 62$ & 2.03 & 1691 & 9.8 & 45.5 & 33.1 & 1.00 \\
E & $\mathrm{C}_{6} \mathrm{~N}_{14} \mathrm{O}_{12} \mathrm{~F}_{2}$ & $551 \pm 63$ & 2.07 & 1398 & 9.3 & 41.6 & 29.8 & 1.08 \\
$\mathrm{~F}$ & $\mathrm{C}_{6} \mathrm{H}_{1} \mathrm{~N}_{14} \mathrm{O}_{12} \mathrm{~F}_{3}$ & $623 \pm 69$ & 2.09 & 1367 & 9.4 & 42.6 & 31.1 & 1.08 \\
$\mathrm{G}$ & $\mathrm{C}_{6} \mathrm{~N}_{14} \mathrm{O}_{12} \mathrm{~F}_{4}$ & $492 \pm 62$ & 2.14 & 1272 & 9.3 & 42.4 & 30.1 & 1.17 \\
{$[5,6,32]$} & $\mathrm{RDX}$ & 79.00 & 1.80 & 1501 & 8.8 & 34.7 & 28.0 & 0.67 \\
{$[5,6,34]$} & $\mathrm{HMX}_{447]}$ & 102.41 & 1.90 & 1498 & 9.1 & 39.3 & 32.0 & 0.67 \\
{$[6]$} & $\mathrm{C}_{4} \mathrm{H}_{6} \mathrm{~N}_{8} \mathrm{O}_{4}$ & 592.09 & 1.82 & 1574 & 8.7 & 33.4 & & \\
{$[5]$} & $\mathrm{C}_{6} \mathrm{H}_{2} \mathrm{~N}_{14} \mathrm{O}_{12}$ & 443.73 & 1.88 & 1621 & 9.1 & 37.7 & & \\
{$[48]$} & $\mathrm{C}_{3} \mathrm{H}_{2} \mathrm{~N}_{12} \mathrm{O}_{5}$ & 740.56 & 1.82 & 1605 & 8.9 & 35.7 & & \\
\hline & $\mathrm{C}_{6} \mathrm{H}_{6} \mathrm{~N}_{12} \mathrm{O}_{12}$ & & 2.04 & 1567 & 9.6 & 44.1 & & \\
\hline
\end{tabular}

The detonation velocity VD and pressure PD are the indicators of HEDM performance. It is expected for the best material to have high detonation velocity and pressure. As seen from Table 3, the designed compounds B, C and $D$ show a slight elevation in VD from $9.5 \mathrm{~km} \mathrm{~s}^{-1}$ for the original A to $9.8 \mathrm{~km} \mathrm{~s}^{-1}$ for $D$ that is a bit greater compared to the reference materials, $8.7-9.4 \mathrm{~km} \mathrm{~s}^{-1}$. There is a rise in pressures of detonation from $\sim 42 \mathrm{GPa}$ for non-fluorinated compound $\mathrm{A}$ to $\sim 46 \mathrm{GPa}$ for di-fluorinated compound $D$. This can be associated with the number of hydrazine fluorinated bonds in these molecules. Among all, the B and $D$ have the highest pressures. The values of PD are comparable to those of nearly related and traditional energetic materials $\mathrm{HMX}(39.3 \mathrm{GPa})$ and $\mathrm{C}_{6} \mathrm{H}_{6} \mathrm{~N}_{12} \mathrm{O}_{12}$ (44.1 $\mathrm{GPa})$. The elevation in detonation pressures and velocity observed for some of our designed species is an indication that fluorination helps in increasing the energy density of the materials.

The impact sensitivity $h_{50 \%}$ is the indicator of the safeness of the material, and it shows how the material responds to external stimuli such as shock and friction. It is measured in terms of drop height that is the height from which fifty percent of the drops result in the reaction of the sample [42]; and the higher the value of $h_{50 \%}$, the lower the impact sensitivity [5]. It is expected that the best material will have moderate sensitivity which is comparable to that of common explosives. The computed impact sensitivities of all designed compounds range from 30 to $33 \mathrm{~cm}$, that is comparable to those of common energetic materials $\mathrm{HMX}$ $(32 \mathrm{~cm})$ and RDX $(28 \mathrm{~cm})$.

The degree of self-oxidation a of the compound indicates the ability of the material to detonate and associated with the content of oxidant, oxygen and fluorine in our case. The higher value of a indicates that the material is more feasible for self-oxidation. For the compounds $A-G$, the values of a obtained by Eq. (16) are between 0.92 and 1.17 (Table 3). Compounds C, D, E, F, and G have coefficients of oxidation greater or equal to one, which is acceptable for HEDM.

Overall, among newly designed compounds, B and $D$ exhibit improved energetic properties compared to other fluorinated triazoles as well as original compound A. Regarding most informative properties, the detonation heat, velocity and pressure, the compounds $B$ and $D$ are predicted to be on the top of the rank. We suppose their enhanced energetic characteristics relate to the structural features, namely, fluorination of the hydrazine chain. At the same time, the fluorination of the triazole rings impairs the properties.

\section{Conclusion}

In this study, we designed fluorinated HEDMs by introducing fluorine atoms into original bridged trinitromethyl azo triazoles molecule to obtain mono-, di-, tri- and tetrafluorinated species. Molecular geometries, infrared spectra, frontier molecular orbitals, thermodynamic and energetic properties were computed and analyzed. The position and number of fluorine substituents resulted in a noticeable change in the enthalpies of formation of gaseous and solid compounds. Generally, introduction of the F atoms into azo linkage brings to an elevation of energetic properties while the triazole ring fluorination lowers the detonation characteristics. Among the designed triazoles, the species with only fluorinated hydrazine chain may be regarded as potential candidates of HEDM with advanced energetic properties compared to common explosives. Our results provide basic information for invention and synthesis of novel energetic materials. 
Acknowledgements Many thanks to the University of Buea, Cameroon, for computational facility access. Also many thanks should go to Mr. Geradius Deogratias, Mr. Rene Costa and Ms. Catherine Paschal from School of Materials, Energy, Water and Environmental Sciences (MEWES) of the Nelson Mandela African Institution of Science and Technology (NM-AIST) for their support and encouragement. Moreover, the abundant appreciation to the Nelson Mandela African Institution of Science and Technology (NM-AIST) lab management for the provision of working places.

\section{Compliance with ethical standards}

Conflict of interest Authors declare no conflict of interest.

\section{References}

1. Yin $\mathrm{P}, \mathrm{JnM} \mathrm{S}$ (2015) From $\mathrm{N}$-nitro to $\mathrm{N}$-nitroamino: preparation of high-performance energetic materials by introducing nitrogen-containing ions. Angew Chem Int Ed 54(48):14513-14517

2. Ye C, Gard GL, Winter RW, Syvret RG, Twamley B, JnM S (2007) Synthesis of pentafluorosulfanylpyrazole and pentafluorosulfanyl-1,2,3-triazole and their derivatives as energetic materials by click chemistry. Org Lett 9(19):3841-3844

3. Bushuyev OS, Brown P, Maiti A, Gee RH, Peterson GR, Weeks BL, Hope-Weeks LJ (2012) lonic polymers as a new structural motif for high-energy-density materials. J Am Chem Soc 134(3):1422-1425

4. Wei T, Zhu W, Zhang J, Xiao H (2010) DFT study on energetic tetrazolo-[1,5-b]-1,2,4,5-tetrazine and 1,2,4-triazolo-[4,3-b]1,2,4,5-tetrazine derivatives. J Hazard Mater 179(1-3):581-590

5. He P, Mei H, Yang J, Zhang J (2019) Design and properties of a new family of bridged bis (nitraminotetrazoles) as promising energetic materials. New J Chem 43(10):4235-4241

6. He P, Zhang J, Wu J (2019) DFT studies on new family of highenergy density energetic bis (trinitromethyl) azo tetrazoles and triazoles. J Phys Org Chem 32(7):e3953

7. Karaghiosoff $K$, Klapötke TM, Michailovski A, Nöth $H$, Suter M, Holl G (2003) 1,4-Diformyl-2,3,5,6-tetranitratopiperazine: a new primary explosive based on glyoxal. Propellants Explos Pyrotech Int J Deal Sci Technol Asp Energ Mater 28(1):1-6

8. Holl G, Klapötke TM, Polborn K, Rienäcker C (2003) Structure and bonding in 2-diazo-4,6-dinitrophenol (DDNP). Propellants Explos Pyrotech Int J Deal Sci Technol Asp Energ Mater 28(3):153-156

9. Fischer N, Karaghiosoff K, Klapötke TM, Stierstorfer J (2010) New energetic materials featuring tetrazoles and nitraminessynthesis, characterization and properties. Z Anorg Allg Chem 636(5):735-749

10. Thottempudi V, JnM S (2011) Synthesis and promising properties of a new family of high-density energetic salts of 5-nitro-3-trinitromethyl-1 H-1,2,4-triazole and 5,5'-Bis (trinitromethyl)-3,3'-azo-1 H-1,2,4-triazole. J Am Chem Soc 133(49):19982-19992

11. Semenov VV, Shevelev SA, Bruskin AB, Shakhnes AK, Kuz'min VS (2017) Synthesis of 5,5'-dinitro-2,2'-bis (polynitromethyl)-bi (1,2,3(4)-triazoles), hydrogen-free oxidizers. Chem Heterocycl Compd 53(6-7):728-732

12. He P, Zhang JG, Yin X, Wu JT, Wu L, Zhou ZN, Zhang TL (2016) Energetic salts based on tetrazole $\mathrm{N}$-oxide. Chem Eur J 22(23):7670-7685

13. Türker $L$ (2016) Azo-bridged triazoles: green energetic materials. Def Technol 12(1):1-15
14. Keshavarz MH, Pouretedal HR (2004) An empirical method for predicting detonation pressure of $\mathrm{CHNOFCl}$ explosives. Thermochim Acta 414(2):203-208

15. Ostrovskii V, Popova E, Trifonov R (2017) Developments in tetrazole chemistry (2009-16). Advances in heterocyclic chemistry, vol 123. Elsevier, Amsterdam, pp 1-62

16. Politanskaya LV, Selivanova GA, Panteleeva EV, Tretyakov EV, Platonov VE, Nikul'shin PV, Vinogradov AS, Zonov YV, Karpov VM, Mezhenkova TV, Vasilyev AV, Koldobskii AB, Shilova OS, Morozova SM, Burgart YV, Shchegolkov EV, Saloutin VI, Sokolov VB, Aksinenko AY, Nenajdenko VG, Moskalik MY, Astakhova VV, Shainyan BA, Tabolin AA, loffe SL, Muzalevskiy VM, Balenkova ES, Shastin AV, Tyutyunov AA, Boiko VE, Igumnov SM, Dilman AD, Adonin NY, Bardin VV, Masoud SM, Vorobyeva DV, Osipov SN, Nosova EV, Lipunova GN, Charushin VN, Prima DO, Makarov AG, Zibarev AV, Trofimov BA, Sobenina LN, Belyaeva KV, Sosnovskikh VY, Obydennov DL, Usachev SA (2019) Organofluorine chemistry: promising growth areas and challenges. Russ Chem Rev 88(5):425-569. https://doi.org/10.1070/rcr4871

17. Sheremetev AB, Palysaeva NV, Struchkova MI, Suponitsky KY, Antipin MY (2012) Copper-catalyzed C-N coupling reactions of nitrogen-rich compounds-reaction of lodofurazans with s-tetrazinylamines. Eur J Org Chem 11:2266-2272

18. Palysaeva NV, Gladyshkin AG, Vatsadze IA, Suponitsky KY, Dmitriev DE, Sheremetev AB (2019) N-(2-Fluoro-2,2-dinitroethyl) azoles: a novel assembly of diverse explosophoric building blocks for energetic compound design. Organ Chem Front 6(2):249-255

19. Dalinger IL, Kormanov AV, Suponitsky KY, Muravyev NV, Sheremetev AB (2018) Pyrazole-tetrazole hybrid with trinitromethyl, fluorodinitromethyl, or (difluoroamino) dinitromethyl groups: high-performance energetic materials. Chem Asian J 13(9):1165-1172

20. Ma X, Cai C, Sun W, Song W, Ma Y, Liu X, Xie G, Chen S, Gao S (2019) Enhancing energetic performance of multinuclear Ag (I)cluster MOF-based high-energy-density materials by thermal dehydration. ACS Appl Mater Interfaces 11(9):9233-9238

21. Lee K-Y, Storm C, Hiskey M, Coburn M (1991) An improved synthesis of 5-amino-3-nitro-1 H-1,2,4-triazole (ANTA), a useful intermediate for the preparation of insensitive high explosives. J Energ Mater 9(5):415-428

22. Martinez H, Zheng Z, Dolbier WR Jr (2012) Energetic materials containing fluorine. Design, synthesis and testing of furazancontaining energetic materials bearing a pentafluorosulfanyl group. J Fluorine Chem 143:112-122

23. Zhang J, Liu Y, Zhou J, Bi F, Wang B (2019) Effect of fluoro substituents on polynitroarylenes: design, synthesis and theoretical studies of fluorinated nitrotoluenes. ChemPlusChem 84(1):92-97

24. Becke $A D$ (1993) A new mixing of Hartree-Fock and local density-functional theories. J Chem Phys 98(2):1372-1377

25. Wei T, Zhu W, Zhang X, Li Y-F, Xiao H (2009) Molecular design of 1,2,4,5-tetrazine-based high-energy density materials. J Phys Chem A 113(33):9404-9412

26. Frisch $M$, Trucks $G$, Schlegel $H$, Scuseria G, Robb M, Cheeseman J, Scalmani G, Barone V, Mennucci B, Petersson G (2009) Gaussian 09; Gaussian, Inc. Wallingford, CT 32:5648-5652

27. Tokarev K (2007) OpenThermo v.1.0 Beta 1 (C) ed. 2007-2009. http://openthermosoftwareinformercom/

28. Lu T, Chen F (2012) Multiwfn: a multifunctional wavefunction analyzer. J Comput Chem 33(5):580-592

29. Ali S, Banck M, Braithwaite R, Bunt J, Curtis D, Fox N, Hanwell $M$, Hutchison G, Benoit J, Lonie D Avogadro: an open-source molecular builder and visualization tool, version 1.0.3

30. Zhurko GA, Zhurko DA. Chemcraft. Version 1.7 (Build 132). https ://www.chemcraftprog.com 
31. Gurvich L, Yungman V, Bergman G, Veitz I, Gusarov A, lorish V, Leonidov VY, Medvedev V, Belov G, Aristova N (1992) Thermodynamic properties of individual substances. Ivtanthermo for windows database on thermodynamic properties of individual substances and thermodynamic modeling software. Version

32. Byrd EF, Rice BM (2006) Improved prediction of heats of formation of energetic materials using quantum mechanical calculations. J Phys Chem A 110(3):1005-1013

33. Politzer P, Murray JS, Edward Grice M, Desalvo M, Miller E (1997) Calculation of heats of sublimation and solid phase heats of formation. Mol Phys 91(5):923-928

34. Rice BM, Pai SV, Hare J (1999) Predicting heats of formation of energetic materials using quantum mechanical calculations. Combust Flame 118(3):445-458

35. Espinosa E, Souhassou M, Lachekar H, Lecomte C (1999) Topological analysis of the electron density in hydrogen bonds. Acta Crystallogr Sect B Struct Sci 55(4):563-572

36. Politzer P, Martinez J, Murray JS, Concha MC, Toro-Labbé A (2009) An electrostatic interaction correction for improved crystal density prediction. Mol Phys 107(19):2095-2101

37. Wang G, Xiao H, Ju X, Gong X (2006) Calculation of detonation velocity, pressure, and electric sensitivity of nitro arenes based on quantum chemistry. Propellants Explos Pyrotech Int J Deal Sci Technol Asp Energ Mater 31(5):361-368

38. Politzer P, Murray JS, Seminario JM, Lane P, Grice ME, Concha MC (2001) Computational characterization of energetic materials. J Mol Struct (Thoechem) 573(1-3):1-10

39. Keshavarz MH (2008) Estimating heats of detonation and detonation velocities of aromatic energetic compounds. Propellants Explos Pyrotech Int J Deal Sci Technol Asp Energ Mater 33(6):448-453

40. Keshavarz MH (2005) A simple approach for determining detonation velocity of high explosive at any loading density. J Hazard Mater 121(1-3):31-36
41. Fischer D, Klapötke TM, Piercey DG, Stierstorfer J (2013) Synthesis of 5-aminotetrazole-1 N-oxide and Its Azo derivative: a key step in the development of new energetic materials. Chem $A$ Eur J 19(14):4602-4613

42. Rice BM, Hare JJ (2002) A quantum mechanical investigation of the relation between impact sensitivity and the charge distribution in energetic molecules. J Phys Chem A 106(9):1770-1783

43. Gu B-M, Lin H, Zhu S-G (2014) Ab initio studies of 1,3,5,7-tetranitro-1,3,5,7-tetrazocine/1,3-dimethyl-2-imidazolidinone cocrystal under high pressure using dispersion corrected density functional theory. J Appl Phys 115(14):143509

44. Michalchuk AA, Trestman M, Rudić S, Portius P, Fincham PT, Pulham CR, Morrison CA (2019) Predicting the reactivity of energetic materials: an ab initio multi-phonon approach. J Mater Chem A 7(33):19539-19553

45. Perger W (2003) Calculation of band gaps in molecular crystals using hybrid functional theory. Chem Phys Lett 368(3-4):319-323

46. Mukhanov AE (2014) Electronic excitation energies in crystals of PETN, RDX and HMX. J Phys Conf Ser 500(18):182029

47. Jin X, Hu B, Jia H, Liu Z, Lu C (2014) DFT theoretical study of energetic nitrogen-rich $\mathrm{C} 4 \mathrm{~N} 6 \mathrm{H} 8-\mathrm{n}(\mathrm{NO} 2) n$ derivatives. Quim Nova 37(1):74-80

48. Politzer P, Murray JS (2011) Some perspectives on estimating detonation properties of $\mathrm{C}, \mathrm{H}, \mathrm{N}, \mathrm{O}$ compounds. Cent Eur J Energ Mater 8(3):209-220

Publisher's Note Springer Nature remains neutral with regard to jurisdictional claims in published maps and institutional affiliations. 